\title{
METODE DAN STRATEGI PENERJEMAHAN ISTILAH-ISTILAH PRAGMATIK DALAM BUKU "PRAGMATICS" KARYA GEORGE YULE KE DALAM BAHASA INDONESIA
}

\author{
Cipto Wardoyo \\ UIN Sunan Gunung Djati Bandung \\ (cipto_w@yahoo.com)
}

\begin{abstract}
This study tries to explain methods and strategies in translating pragmatic terms were used by translators in translating pragmatic terms. Source of data in this study was the book written by George Yule entitled "Pragmatics" (1996) which was translated into Indonesian language by Fajar Indah Wahyuni (2014).The writer in this research used the theory of translation method by Newmark (1988) and translation strategies by Vinay \& Dalbernet (2000) and Baker (1992). The results of this study shows that the most dominant translation method was literal translation, it was $72 \%$ from the total data, faithful translation method was $10 \%$, semantic translation was $10 \%$, free translation method was $5 \%$, and communicative translation method was 3\%. Moreover, strategies of translating pragmatic terms in the book "pragmatics" by George Yule the dominant strategy was naturalization strategy was $66 \%$ from the total data, Calque was 28\%, transposition was $4 \%$, and tranferency was $3 \%$.
\end{abstract}

Keywords: Translation, Methods, Strategies, Pragmatic Terms

\section{LATAR BELAKANG}

Kendala bahasa menjadi masalah yang cukup serius dalam proses alih informasi, ilmu pengetahuan dan teknologi di Indonesia. Peran dari aktifitas penerjemahan memegang peran penting dalam mengatasi kendala bahasa dalam transfer IPTEKS (ilmu pengetahuan, teknologi dan seni) ke negeri kita. Kondisi lemahnya kemampuan bahasa asing menyebabkan masyarakat pada umumnya tertinggal informasi mutakhir dalam berbagai bidang karena buku-buku yang membahas isu terkini dalam bidang ilmu pengetahuan, teknologi dan seni menggunakan bahasa Inggris. Penerjemah profesional mampu untuk menyampaikan informasi dari bahasa sumber (Source Language) ke bahasa sasaran (Target Language), sehingga konten informasi yang ada dalam bahasa sumber dapat disampaikan sama persis ke dalam bahasa sasaran. Dapat disimpulkan bahwa dengan membaca hasil terjemahan pembaca mendapatkan informasi dari teks yang sama dengan naskah aslinya, tentunya aktifitas penerjemahan ini akan memudahkan masyarakat Indonesia yang belum mampu menguasai bahasa asing untuk dapat memahami teks-teks berkaitan tentang ilmu pengetahuan, teknologi dan seni dalam bahasa Inggris yang telah diterjemahkan ke dalam bahasa Indonesia.

Pragmatik adalah salah catu cabang keilmuan dalam kajian 
linguistik atau ilmu bahasa yang sangat populer saat ini. Hal ini ditandai dengan banyaknya penelitian yang menjadikan pragmatik sebagai topik kajiannya. Pragmatik adalah kajian yang tidak hanya membahas makna kata secara leksikal sesuai dengan kamus tetapi membahas makna berdasarkan konteks penuturnya. Pragmatik adalah jawaban terhadap realitas kehidupan masyarakat penutur bahasa bahwa makna tuturan itu tidak bisa diinterpretasikan tanpa melihat konteks atau situasi yang melatarbelakangi tuturan tersebut.

Istilah-istilah pragmatik yang diterjemahkan dari bahasa Inggris ke bahasa Indonesia memiliki keunikan, terkait dengan perbedaan sudut pandang antara penerjemah dan para ahli linguistik. Ini merupakan hal yang sangat menarik untuk ditelusuri lebih dalam, karena konsep pragmatik pada teori linguistik pada mulanya lahir dalam bahasa Inggris, para pakar pragmatik seperti Leech, Grundy, Mey, dan Yule menulis teori-teori pragmatik dalam bahasa Inggris. Ketika buku-buku tentang pragmatik berbahasa Inggris itu diterjemahkan, maka dicari padanan istilah-istilah pragmatik itu ke dalam bahasa sasaran.

Penerjemahan dapat diartikan sebagai suatu proses pemindahan suatu makna atau informasi yang terkandung dalam satu bahasa ke bahasa lain. Larson (1998:3) mengatakan bahwa "Translation consists of transferring the meaning of the source language into receptor language." Larson secara sederhana mendefinisikan penerjemahan sebagai proses pemindahan atau transfer makna dari bahasa sumber (Source Language) ke bahasa sasaran (Target Language).
Pakar penerjemahan yang bernama Newmark (1988:45- 47) mengklasifikasikan metode penerjemahan ke dalam delapan kategori penerjemahan, yaitu penerjemahan kata demi kata, penerjemahan harfiah, penerjemahan setia, penerjemahan semantik, penerjemahan adaptasi, penerjemahan bebas, penerjemahan idiomatik dan penerjemahan komunikatif. Delapan metode penerjemahan yang dikemukakan oleh Newmark itu cukup memberikan solusi, namun pada setiap metode yang dikemukakannya pasti ada kelebihan serta kekurangannya.

Lebih lanjut Barathayomi (2012) mengatakan bahwa beberapa pakar penerjemahan menggunakan istilah yang berbeda dalam memberi terminologi strategi penerjemahan, yakni Vinay dan Dalbernet (2000) dan Baker (1992) menyebutnya sebagai strategi, Hoed (2006) menyebutnya sebagai teknik dan Newmark (1988) menyebutnya sebagai prosedur. Berikut beberapa strategi yang digunakan penerjemah dalam mengatasi berbagai masalah penerjemahan:

1. Transferensi: transferensi adalah istilah yang digunakan oleh Newmark (1988) yang menggunakan istilah dalam bahasa sumber ke dalam bahasa sasaran.

2. Naturalisasi: strategi ini adalah mengadaptasi kata dalam bahasa sumber dan struktur morfologi yang alami ke dalam bahasa sasaran.Misalnya kata "cryphtographic software" diterjemahkan ke dalam bahasa Indonesia menjadi "perangkat lunak kriptografis". 
3. Calque: calque adalah strategi penerjemahan secara literal atau pinjaman untuk kolokasi yang umum atau frasa yang dikenal dalam bahasa sumber, seperti "honeymoon" diterjemahkan menjadi "bulan madu".

4. Modulasi: strategi menerjemahkan sesuatu yang abstrak menjadi kongkrit, kalimat aktif menjadi pasif, mengganti simbol dan sebagainya. Contoh: "tea bag" diterjemahkan menjadi "teh celup".

5. Padanan Budaya: padanan budaya dilakukan dengan mengganti kata atau ekspresi budaya dalam bahasa sumber dengan kata atau eksprsi budaya yang berbeda di bahasa sasaran,

6. Transposisi (Transposition): transposisi adalah pergeseran kelas kata seperti verba menjadi nomina tanpa mengubah makna dari kalimat yang diterjemahkan. Transposisi ini juga bisa terjadi ketika terjemahkan menghasilkan suatu perubahan misalnya: perubahan plural menjadi singular, atau perubahan posisi kata sifat.

Berdasarkan pemaparan di atas maka peneliti sangat tertarik untuk mencoba mendalami metode dan strategi yang digunakan oleh penerjemah dalam penerjemahan istilah-istilah pragmatik yang ada dalam buku "Pragmatics" karangan George Yule ke dalam bahasa Indonesia.

\section{Metode Penelitian}

Metode penelitian yang penulis gunakan adalah metode penelitian kualitatif. Ritche dan Lewis (2003:3) menjelaskan bahwa penelitian kualitatif memberikan arahan yang jelas dalam rangka memahami
Metode Dan Strategi Penerjemahan Istilah-Istilah Pragmatik

fenomena sosial dari partisipan melalui nilai-nilai sosial, pengalaman dan cara pandang mereka. Sedangkan Woods (2006:2) mengatakan bahwa penelitian kualitatif fokus pada kondisi alamiah yang memiliki makna, perspektif, dan pemahaman yang mempertimbangkan proses. Dari pengertian metode penelitian kualitatif di atas dapat disimpulkan bahwa metode kualitatif akan menjelaskan data secara deskriptif, holistik dan menyeluruh mengenai fenomena sosial untuk dilihat sebagai satu kesatuan yang utuh dan komprehensif.

Sumber data dalam penelitian ini adalah buku Pragmatics karangan George Yule (1996) yang diterjemahkan ke dalam Bahasa Indonesia oleh Indah Fajar Wahyuni (2014) dengan judul Pragmatik. Teknik pengambilan data dari penelitian ini menggunakan teknik studi pustaka, dimana penulis mencari beberapa referensi bukubuku yang terkait yang dapat membantu penulis menyelesaikan penelitian ini. Peneliti membaca buku sumber yang menjadi sumber data yang utama, yakni buku Pragmatics,karangan George Yule, maupun buku terjemahannya dalam bahasa Indonesia. Peneliti memberi tanda pada kata, kalimat atau frase yang mengandung istilah-istilah pragmatik dalam bahasa Inggris dan mencari padanannya dalam hasil terjemahannya dalam bahasa Indonesia. Data yang mengandung istilah pragmatik dikumpulkan sehingga menjadi tabulasi data, kemudian data diklasifikasikan berdasarkan kategori metode penerjemahan Newmark (1988) dan strategi penerjemahan oleh Vinay 
dan Dalbernet (2000) dan Baker (1992).

\section{PEMBAHASAN}

Buku "Pragmatics" karangan George Yule (1996) diterjemahkan ke dalam Bahasa Indonesia oleh Indah Fajar Wahyuni (2014) dengan judul "Pragmatik". Tabel di bawah ini adalah temuan data Metode penerjemahan istilah-istilah pragmatik dari bahasa Inggris ke dalam bahasa Indonesia berdasarkan teori Newmark.

Dari hasil analisis data metode perjemahan istilah pragmatik ditemukan bahwa metode penerjamahan yang digunakan dalam menerjemahkan istilah-istilah pragmatik yang paling dominan menggunakan metode penerjemahan harfiah (72\%), metode penerjemahan setia (10\%), metode penerjemahan semantis (10\%), metode penerjemahan bebas (5\%) dan metode penerjemahan komunikatif $(3 \%)$.

Teknik dan strategi penerjemahan istilah-istilah pragmatik dalam buku "pragmatics" karangan George Yule yang diterjemahkan ke dalam bahasa Indonesia dominan menggunakan strategi naturalisasi yakni 52 data (66\%), strategi penerjemahan Calque sebanyak 22 data (28\%), strategi transposisi 3 (4\%), dan strategi transperensi $(3 \%)$.

\section{Analisi Data}

Data 1

Bahasa Sumber (Bsu): Pragmatics is concern with the study of meaning as communicated by a speaker (or writer) and interpreted by a listener (or reader). Page 3

Bahasa Sasaran (Bsa): Pragmatik adalah studi tentang makna yang disampaikan oleh penutur (atau penulis) dan ditafsirkan oleh pendengar (atau pembaca). Halaman 3

Kalimat BSu di atas diterjemahkan ke dalam BSa dengan menggunakan penerjemahan harfiah, kalimat "Pragmatics is concern with the study of meaning as communicated by a speaker (or writer) and interpreted by a listener (or reader)." Diterjemahkan secara literal ke dalam bahasa Indonesia menjadi "Pragmatik adalah studi tentang makna yang disampaikan oleh penutur (atau penulis) dan ditafsirkan oleh pendengar (atau pembaca)". Istilah "pragmatics" diterjemahkan menggunakan strategi naturalisasi menjadi "pragmatik", penerjemahan ini sedikit berbeda dengan pendapat Kridalaksana yang menerjemahkan pragmatik menjadi "pragmatika" (2001:177). Kata "speaker" diterjemahkan secara harfiah menjadi "penutur" dan "interpreted" diterjemahkan juga secara harfiah menjadi "ditafsirkan".

Data 2

$\mathrm{BSu}$ : Pragmatics is study of relationship between linguistics forms and users of those forms. Page 4

Bsa : Pragmatik adalah studi tentang hubungan antara bentuk-bentuk linguistik dan pemakai bentukbentuk itu. Halaman 5

Data di atas menyajikan kalimat BSu yang diterjemahkan ke dalam BSa dengan menggunakan metode penerjemahan harfiah, kalimat "Pragmatics is study of relationship between linguistics forms and users of those forms." diterjemahkan secara literal menjadi "Pragmatik adalah studi tentang hubungan antara bentuk-bentuk 
linguistik dan pemakai bentukbentuk itu." Istilah pragmatik "linguistics forms and users" diterjemahkan menggunakan strategi transposisi menjadi "bentuk-bentuk linguistik dan pemakai". Dari hasil terjemahan "users" dalam bentuk plural menjadi "pemakai" dalam bentuk tunggal bisa disimpulkan bahwa penerjemahan istilah pragmatik pada data di atas menggunakan strategi transposisi.

Data 3

$\mathrm{BSu}$ : Some of that regularity derives from the fact that people are members of social groups and follow general patterns of behavior expected within the group. Page 5

BSa: Sebagian dari peraturan ini berasal dari kenyataan bahwa manusia adalah kelompok sosial dan mengikuti pola-pola tingkahlaku umum yang diharapkan dalam kelompok itu. Halaman 6

Kalimat dalam BSu di atas terjemahkan ke dalam BSa dengan metode penerjemahan harfiah, yakni kalimat "Some of that regularity derives from the fact that people are members of social groups and follow general patterns of behavior expected within the group" diterjemahkan menjadi "Sebagian dari peraturan ini berasal dari kenyataan bahwa manusia adalah kelompok sosial dan mengikuti pola-pola tingkahlaku umum yang diharapkan dalam kelompok itu" . Istilah pragmatik "regularity" diterjemahkan secara harfiah menjadi "peraturan". Sedangkan Kridalaksana (2001: 281) menerjemahkan regularity sebagai "keteraturan" dapat disimpulkan bahwa pengertian dari Kridalaksana lebih berterima dan sepadan untuk menerjemahkan istilah ini.
Metode Dan Strategi Penerjemahan Istilah-Istilah Pragmatik

Data 4

BSu: Deixis is a technical term (from Greek) for one of the most basic things we do with utterances. It means, "pointing" via language.Page 9

BSa: Deiksis adalah istilah teknis (dari bahasa Yunani) untuk salah satu hal yang mendasar yang kita lakukan dengan tuturan. Deiksis berarti "penunjukan" melalui bahasa. Halaman 13

Kalimat dalam BSu pada data di atas diterjemahkan ke dalam BSa menggunakan metode penerjemahan harfiah, kalimat "Deixis is a technical term (from Greek) for one of the most basic things we do with utterances. It means, "pointing" via language." diterjemahkan menjadi "Deiksis adalah istilah teknis (dari bahasa Yunani) untuk salah satu hal yang mendasar yang kita lakukan dengan tuturan. Deiksis berarti "penunjukan" melalui bahasa". Istilah pragmatik "deixis" diterjemahkan menggunakan strategi naturalisasi menjadi "deiksis", sedangkan istilah "pointing" diterjemahkan secara literal menjadi "penunjukan". Ini sejalan dengan pendapat Kridalaksana (2001:249) yang menerjemahkan deixis sebagai deiksis.

Data 5

BSu: Deictic expressions are also sometimes called indexicals. Page 9 BSa: Ungkapan-ungkapan deiksis kadang-kadang juga disebut indeksikal. Halaman 13

Data di atas menggambarkan bahwa kalimat dalam BSu diterjemahkan ke dalam BSa menggunakan metode penerjemahan harfiah. Kalimat "Deictic expressions are also sometimes called indexicals" diterjemahkan secara 
harfiah atau literal menjadi "Ungkapan-ungkapan deiksis kadang-kadang juga disebut indeksikal". Istilah pragmatik "Deictic expressions' dan "indexicals" diterjemahkan menggunakan strategi naturalisasi menjadi "Ungkapan-ungkapan deiksis" dan "indeksikal”.

Data 6

BSu: Can be used to indicate people via person deixis (me, you), or location via spatial deixis (here, there), or time via temporal deixis (now, then).Page 9

BSa: Dapat digunkan untuk menunjuk orang dengan deiksis persona $(\mathrm{ku}, \mathrm{mu})$ atau untuk menunjuk tempat dengan deiksis spasial (disini, disana), atau menunjuk waktu dengan dieksis temporal (sekarang, kemudian). Halaman 14

Data di atas menunjukan bahwa kalimat dalam BSu diterjemahkan secara harfiah ke dalam BSa, kalimat "Can be used to indicate people via person deixis (me, you), or location via spatial deixis (here, there), or time via temporal deixis (now, then)" diterjemahkan menjadi "Dapat digunkan untuk menunjuk orang dengan deiksis persona (ku, mu) atau untuk menunjuk tempat dengan deiksis spasial (disini, disana), atau menunjuk waktu dengan dieksis temporal (sekarang, kemudian)" . Istilah pragmatik pada data di atas yakni "person deixis, spatial deixis, temporal deixis" yang diterjemahkan dengan strategi naturalisasi "deiksis persona, deiksis spasial, dieksis temporal".

Data 7

BSu: In English the "near speaker" or proximal terms, are "this, here, now". The "away from the speaker" or distal terms "that, there, then". Page 9

BSa: Dalam bahasa Inggris "dekat penutur" atau istilah-istilah proksimal, adalah "ini, di sini, sekarang" sedangkan jauh dari penutur atau istilah-istilah distal adalah "itu, di sana, pada saat itu". Halaman 14

Kalimat dalam BSu "In English the "near speaker" or proximal terms, are "this, here, now". The "away from the speaker" or distal terms "that, there, then" diterjemahkan dengan metode harfiah menjadi "Dalam bahasa Inggris "dekat penutur" atau istilahistilah proksimal, adalah "ini, di sini, sekarang" sedangkan jauh dari penutur atau istilah-istilah distal adalah "itu, di sana, pada saat itu". Istilah-istilah pragmatik pada kalimat di data di atas yakni "proximal terms" dan "distal terms" diterjemahkan dengan strategi naturalisasi menjadi "istilah-istilah proksimal" dan "istilah-istilah distal".

Data 8

BSu: Expressions which indicate higher status are described as honorifics. Page 9

BSa: Ungkapan-ungkapan yang menunjukan status lebih tinggi dideskripsikan sebagai honorifics. Halaman 15

Data pada kalimat di atas, kalimat BSu diterjemahkan secara harfiah ke dalam BSa. Kalimat "Expressions which indicate higher status are described as honorifics" diterjemahkan secara literal menjadi "Ungkapan-ungkapan yang menunjukan status lebih tinggi dideskripsikan sebagai honorifics." Istilah pragmatik "honorifics" 
diterjemahkan dengan menggunakan strategi transferensi atau peminjaman murni menjadi "honorifics" yakni kata lexical di dalam BSu digunakan secara utuh pula di BSa.

\section{Data 9}

$\mathrm{BSu}$ : The discussion of the circumstances which lead to the choice of one of these forms rather than another is sometimes described as social deixis. Page 10

BSa: Pembahasan tentang keadaan sekitar yang mengarah pada pemilihan salah satu bentuk ini dari pada bentuk lain kadang kadang dideskripsikan sebagai deiksis social Halaman 16

Kalimat BSu pada data di atas diterjemahkan ke dalam BSa dengan menggunakan penerjemahan harfiah. Kalimat "The discussion of the circumstances which lead to the choice of one of these forms rather than another is sometimes described as social deixis" diterjemahkan secara literal ke dalam BSa menjadi "Pembahasan tentang keadaan sekitar yang mengarah pada pemilihan salah satu bentuk ini dari pada bentuk lain kadang kadang dideskripsikan sebagai deiksis sosial". Istilah pragmatik pada data di atas yakni "social deixis" diterjemahkan dengan strategi naturalisasi menjadi "deiksis sosial".

\section{Data 10}

BSu: We might best think of reference as an act in which a speaker, or writer, uses linguistic forms to enable a listener, or reader, to identify something. Page 17

BSa: Barangkali paling baik kita memikirkan tentang referensi sebagai suatu tindakan di mana seorang penutur, penulis,
Metode Dan Strategi Penerjemahan Istilah-Istilah Pragmatik

menggunakan bentuk linguistik untuk memungkinkan seorang pendegar atau pembaca mengenali sesuatu. Halaman 27

Kalimat Bsu "We might best think of reference as an act in which a speaker, or writer, uses linguistic forms to enable a listener, or reader, to identify something" diterjemahkan secara literal ke dalam BSu menjadi "Barangkali paling baik kita memikirkan tentang referensi sebagai suatu tindakan di mana seorang penutur, penulis, menggunakan bentuk linguistik untuk memungkinkan seorang pendengar atau pembaca mengenali sesuatu". Istilah pragmatik pada data di atas "reference" diterjemahkan dengan strategi naturalisasi menjadi "referensi".

Data 11

BSu: Those linguistic forms are referring expressions, which can be proper nouns for example : Shakespear, Cathy Revuelto, Hawaii. Page 17

BSa: Bentuk-bentuk lingustik itu adalah ungkapan-ungkapan pengacuan, yang mungkin berupa nama diri (misalnya: Shakespear, Cathy Revuelto, Hawaii) Halaman 28

Data di atas menjelaskan bahwa kalimat dalam bahasa sumber "Those linguistic forms are referring expressions, which can be proper nouns for example : Shakespear, Cathy Revuelto, Hawaii" diterjemahkan secara harfiah atau literal menjadi "Bentuk-bentuk lingustik itu adalah ungkapanungkapan pengacuan, yang mungkin berupa nama diri (misalnya: Shakespear, Cathy Revuelto, Hawaii)". Istilah pragmatik pada kalimat di atas yakni "referring 


\author{
expression" diterjemahkan \\ menggunakan strategi calque \\ menjadi"ungkapan-ungkapan \\ pengacuan".
}

\section{Data 12}

BSu: It is called zero anaphora, or ellipsis. Page 23

BSa: Penafsiran ini disebut anafor zero atau ellipsis. Halaman 39

Kalimat BSu pada data di atas diterjemahkan ke dalam BSa dengan menggunakan metode penerjemahan komunikatif, yakni kalimat "It is called zero anaphora, or ellipsis “ diterjemahkan secara komunikatif menjadi "Penafsiran ini disebut anafor zero atau ellipsis". Pada data di atas "it" di dalam BSu diterjemahkan secara komunikatif menjadi "penafsiran ini" untuk memperjelas makna ke dalam BSa. Istilah pragmatik "zero anaphor" dan "ellipsis" diterjemahkan dengan strategi naturalisasi menjadi "anafor zero" dan "ellipsis".

\section{Data 13}

BSu: For successful reference to occur, we must also recognize the role of inference. Because there is no direct relation between entities and words. Page 17

BSa: Agar terjadi referensi yang sukses kita juga harus mengenali peran inferensi. Karena tidak ada hubungan langung antara intitasintitas dan kata-kata. Halaman 28

Kalimat BSu pada data di atas diterjemahkan ke dalam BSa dengan menggunakan metode penerjemahan harfiah, kalimat "For successful reference to occur, we must also recognize the role of inference. Because there is no direct relation between entities and words" diterjemahkan menjadi "Agar terjadi referensi yang sukses kita juga harus mengenali peran inferensi. Karena tidak ada hubungan langung antara intitas-intitas dan kata-kata" . Istilah pragmatik "inference" diterjemakan dengan strategi naturalisasi menjadi "inferensi".

Data 14

BSu: This is sometimes called an attributive use, meaning :whoever/whatever fits the description. Page 18

BSa: Inilah yang kadang kala disebut dengan pemakaian atributif, yang berarti " siapa saja/ apa saja yang sesuai dengan uraiannya". Halaman 30

Data di atas menjelaskan bahwa kalimat dalam bahasa sumber "This is sometimes called an attributive use, meaning :whoever/whatever fits the description" diterjemahkan ke dalam bahasa sasaran menjadi "Inilah yang kadang kala disebut dengan pemakaian atributif, yang berarti “ siapa saja/ apa saja yang sesuai dengan uraiannya". Istilah pragmatik dalam kalimat di atas "atrributive use" diterjemahkan secara calque menjadi "pemakaian atributif".

Data 15

BSu: It would be distinct from a referential use whereby I actually have a person in mind and, instead of using her name or some other description.Page 18

BSa: Pemakaian atributuf itu berbeda dengan pemakaian referensial, dimana saya biasanya memiliki seseorang di dalam pemikiran saya, dan saya memilih ungkapan daripada memakai namanya atau deskripsi apapun.Halaman 30

Kalimat BSu pada data di atas diterjemahkan ke dalam BSa dengan menggunakan metode penerjemahan 
setia, kalimat "It would be distinct from a referential use whereby $I$ actually have a person in mind and, instead of using her name or some other description" diterjemahkan menjadi "Pemakaian atributuf itu berbeda dengan pemakaian referensial, dimana saya biasanya memiliki seseorang di dalam pemikiran saya, dan saya memilih ungkapan daripada memakai namanya atau deskripsi apapun." Istilah pragmatik "a referential use" diterjemahkan dengan menggunakan strategi naturalisasi menjadi "pemakaian referensial".

\section{Data 16}

$\mathrm{BSu}$ : The appears to be a pragmatic connection between proper names and objects that will be conventionally associated, within a socioculturally defined community, with those names. Page 20

BSa: Di sana tampak adanya suatu hubungan pragmatik antara nama diri dengan objek-objek yang akan diasosiasikan secara konvensional, di dalam suatu masyarakat yang didefinisikan secara sosio cultural, dengan nama-nama itu. Halaman 34

Kalimat pada di atas BSu diterjemahkan dengan menggunakan metode penerjemahan semantic ke dalam BSa. Kalimat "The appears to be a pragmatic connection between proper names and objects that will be conventionally associated, within a socioculturally defined community, with those names" diterjemahkan secara semantis ke dalam bahasa Indonesia menjadi "Di sana tampak adanya suatu hubungan pragmatik antara nama diri dengan objek-objek yang akan diasosiasikan secara konvensional, di dalam suatu masyarakat yang didefinisikan secara sosio cultural, dengan nama-nama
Metode Dan Strategi Penerjemahan Istilah-Istilah Pragmatik

itu". Istilah pragmatik pada data di atas diterjemahkan dengan strategi naturalisasi, yakni "pragmatic connection" menjadi "koneksi pragmatik" , sedangkan istilah "socioculturally" yang diterjemahkan secara transposisi menjadi" secara sosio kultural".

Data 17

BSu: It has been aided by the linguistic material, or co-text, accompanying the referring expression. Page 21

BSa: Kemampuan mengenali referen itu telah dibantu oleh materi linguistik, atau ko-teks yang menyertai ungkapan pengacuan itu. Halaman 35

$\begin{array}{cccc}\text { Pada } & \text { data di } & \text { atas, kalimat } \\ \text { dalam } & \mathrm{BSu} & & \text { diterjemahkan }\end{array}$ menggunakan metode penerjemahan bebas ke dalam BSa. Kalimat "It has been aided by the linguistic material, or co-text, accompanying the referring expression" diterjemahkan dengan menggunakan metode penerjemahan bebas dengan parafrasa menjadi "Kemampuan mengenali referen itu telah dibantu oleh materi linguistik, atau ko-teks yang menyertai ungkapan pengacuan itu.". Istilah pragmatik "linguistic material" diterjemahkan secara naturalisasi menjadi "materi linguistik" begitupun "co-text" diterjemahkan juga dengan strategi naturalisasi menjadi "ko-teks". Sedangkan istilah "the referring expression" diterjemahkan dengan menggunakan strategi calque menjadi "ungkapan pengacuan".

Data 18

$\mathrm{BSu}$ : The referring expression actually provides a range of reference, that is, a number of possible referents. Page 21 
BSa: Ungkapan pengacuan sebenarnya memberikan rentangan referensi, yaitu sejumlah referensi yang memungkinkan. Halaman 35

Kalimat dalam BSu pada data di atas diterjemahkan menggunakan metode penerjemahan harfiah ke dalam BSa, kalimat "The referring expression actually provides a range of reference, that is, a number of possible referents" diterjemahkan secara literal ke dalam bahasa Indonesia menjadi "Ungkapan pengacuan sebenarnya memberikan rentangan referensi, yaitu sejumlah referensi yang memungkinkan". Istilah pragmatik pada kalimat di atas yakni " a range of reference" diterjemahkan dengan strategi transposisi menjadi "rentangan referensi" , pada penerjemahan istilah tersebut preposisi dalam bahasa Inggris “of” dihilangkan .

Data 19

BSu: The pronoun (it, he, her, they) are examples of subsequent reference to already introduce referents, generally known as anaphoric reference, or anaphora. Page 22

BSa: Kata-kata ganti (dia binatang, dia laki-laki, nya, mereka) adalah contoh referensi selanjutnya terhadap referensi yang sudah diperkenalkan biasanya dikenal sebagai referensi anaforik atau anaphora. Halaman 37

$\begin{array}{rlll}\text { Pada } & \text { data di atas, kalimat } \\ \text { dalam } & \mathrm{BSu} & & \text { diterjemahkan }\end{array}$ menggunakan metode penerjemahan komunikatif ke dalam BSa, kalimat "The pronoun (it, he, her, they) are examples of subsequent reference to already introduce referents" diterjemahkan menjadi "Kata-kata ganti (dia binatang, dia laki-laki, nya, mereka) adalah contoh referensi selanjutnya terhadap referensi yang sudah diperkenalkan". Istilah-istilah pragmatik pada data di atas "it, he, her, they" diterjemahkan menjadi "dia binatang, dia laki-laki, nya, mereka" dengan strategi padanan budaya. Istilah "referents" diterjemahkan menggunakan strategi naturalisasi menjadi "referensi", istilah pragmatik yang lainnya adalah "anaphoric reference" diterjemahkan dengan strategi naturalisasi menjadi "referensi anaforik" sedangkan istilah "anaphora." Diterjemahkan dengan strategi transferensi yakni peminjaman murni menjadi "anaphora" penggunaan BSu tanpa ada perubahahan ke dalam BSa.

Data 20

$\mathrm{BSu}$ : The expression is the anaphor and the initial is the antecendent. Page 23

BSa: Ungkapan-ungkapan itu disebut anafor dan ungkapan awal disebut antesenden. Halaman 37

Kalimat dalam dalam BSu pada data di atas diterjemahkan dengan menggunakan metode penerjemahan harfiah ke dalam BSa. Kalimat "The expression is the anaphor and the initial is the antecendent" diterjemahkan secara harfiah atau literal menjadi "Ungkapan-ungkapan itu disebut anafor dan ungkapan awal disebut antesenden". Istilah pragmatik pada data di atas, yakni "anaphor" dan "antecendent" diterjemahkan dengan strategi naturalisasi menjadi "anafor" dan "antesenden".

Data 21

$\mathrm{BSu}$ : The pattern is technically known as cataphora, and is much less common than anaphora. Page 23

BSa; Pola ini secara teknis dikenal sebagai katafora, dan lebih tidak 
umum dibanding dengan anaphora. Halaman 38

Data di atas menyajikan kalimat BSu yang diterjemahkan ke dalam BSa dengan menggunakan metode penerjemahan harfiah, kalimat "The pattern is technically known as cataphora, and is much less common than anaphora" diterjemahkan menjadi "Pola ini secara teknis dikenal sebagai katafora, dan lebih tidak umum dibanding dengan anaphora". Istilah pragmatik "anaphora" dan "cataphora" diterjemahkan menjadi "katafora" dan "anaphora" sesuai dengan strategi naturalisasi.

\section{SIMPULAN}

Dari hasil analis data dapat disimpulkan bahwa di dalam metode penerjemahan istilah-istilah pragmatik di buku "Pragmatics" karangan George Yule, metode yang paling dominan digunakan adalah metode penerjemahan harfiah $(72 \%)$. Selanjutnya, metode penerjemahan setia digunakan sebesar $10 \%$, angka ini sama dengan penggunaan metode penerjemahan semantis yang juga sebesar $10 \%$ dari totsl data. Metode yang jarang digunakan adalah metode penerjemahan bebas $(5 \%)$ dan metode penerjemahan komunikatif (3\%). Hal ini menandakan bahwa penerjemahan buku "pragmatics" karangan George Yule ini masih kaku dan berorientasi pada struktur dan tatanan gramatikal Bahasa Inggris sebagai bahasa sumber.

Teknik dan strategi penerjemahan istilah-istilah pragmatik ke dalam bahasa Indonesia dominan menggunakan strategi naturalisasi yakni 52 data (66\%), strategi penerjemahan Calque sebanyak 22 data (28\%), strategi
Metode Dan Strategi Penerjemahan Istilah-Istilah Pragmatik

transposisi $3(4 \%)$, dan strategi transperensi (3\%). Banyaknya data yang diterjemahkan secara naturalisasi menandakan bahwa istilah-istilah pragmatik banyak diterjemahkan dengan menggunakan teknik peminjaman (borrowing) karena sulit untuk mencari padanan kata yang tepat di dalam bahasa sasaran. Hal ini menandakan bahwa bahasa Inggris sebagai bahasa sumber berpengaruh besar terhadap penerjemahan istilah pragmatik ke dalam bahasa Indonesia.

\section{DAFTAR PUSTAKA}

Baker, Mona.1992. In Other Words: A Coursebook on Translation. London: Routledge.

Bauer, Laurie. 2002. An Introduction toInternational Varietiesof English. Edinburgh: Edinburgh University Press Ltd

Barathayomi, Wieka. 2012. Strategi Penerjemahan Istilah Budaya dalam Novel "Olive Kitteridge": Kritik Terjemahan Berdasarkan Model Analisis Teks yang Berorientasi pada Penerjemahan. Tesis Ilmu Linguistik, Fakultas Ilmu Budaya, Universitas Indonesia.

Choliludin.2013. The Technique of Making Idiomatic Translation. Jakarta: Kesaint Blanc

Djuharie, O. Setiawan. Teknik dan Panduan Menerjemahkan Bahasa Inggris-Bahasa Indonesia. Bandung: $\mathrm{CV}$ Yrama Widya.

Kridalaksana, Harimurti. 2001. Kamus Linguistik. Jakarta: PT Gramedia Pustaka Utama. 
Larson, Mildred L. 1998. Meaning Based Translation: A guide to Cross Language Equivalence. USA : University Press of America.

Machali, Rochayah.2000. Pedoman Bagi Penerjemah. Jakarta: PT Grasindo.

Muntaha, Salihen. 2006. Bahasa dan Terjemahan: Language and Translation the new Millennium Publication. Bekasi Timur: Kesaint Blanc.

Nababan, Donal DJ.2007. Metode, Strategi dan Teknik Penerjemahan: Sebuah Tinjauan Mendalam.Artikel Kongres Linguistik Nasional XX di Surakarta tanggal 3-6 September 2007.Halaman 4356

Newmark, Peter. 1988. A Text Book of Translation. Great Britain: Prentice Hall inc.

Nida, Eugene Albert. 2001. Context In Translating. Netherland: John Benjamins

Ritchie, Jane and Lewis. 2003. Qualitative Research Practice:
A Guide for Social Science Students and Researchers. London: Sage Publications

Silalahi,Roswita. 2009. Dampak teknik, metode, dan ideologi penerjemahan pada kualitas teks Medikal Surgical Nursing dalam bahasa Indonesia .Disertasi S3 Universitas Sumatera Utara.

Wardoyo,Cipto. 2015. Strategi Penerjemahan Istilah-Istilah Pragmatik dalam Buku "Principles of Pragmatics" karangan Geoffrey Leech. Makalah dipresentasikan dalam Seminar Nasional PRASASTI Kajian Pragmatik dalam Berbagai Bidang di UNS 2015

Woods, Peter. 2006. Successful Writing for Qualitative Researchers. London: Routledge

Yule, George. 1996. Pragmatics. Hongkong: Oxford University Press.

Yule, George. 2014. Pragmatik (diterjemahan oleh Indah Fajar Wahyuni). Yogyakarta: Pustaka Pelajar 